\title{
Non-structural carbohydrate metabolism and postharvest conservation of gerbera flowers ${ }^{(1)}$
}

\author{
ANA MARIA OLIVEIRA SOUZA ALVES(2), JAIANNE FRANCIELLE OLIVEIRA SANTOS PIMENTEL(2), \\ GUSTAVO FERREIRA DA SILVA ${ }^{(3)}$, NILBE CARLA MAPELI(3), ANA MARIA MAPELI(2)*
}

\begin{abstract}
The species Gerbera jamesonii Adlam has great economic importance in the ornamental sector, due to exuberance of floral stems. However, florists face some challenges such as postharvest handling and difficulty of conservation. Therefore, this study aimed to characterize the non-structural carbohydrate content in different floral stages of $G$. jamesonii var. Dawn and evaluate the effect of preservative solutions during the postharvest storage of this species. For this purpose, it was quantified TSS, RS and NRS from the seven stages of gerbera stems ontogeny (E1, E2, E3, E4, E5, E6 and E7). The preservative solutions used were: T1) distilled water; T2) citric acid (100 $\left.\mathrm{mg} \mathrm{L}^{-1}\right)$; T3) glucose $\left(20 \mathrm{~g} \mathrm{~L}^{-1}\right)$; T4) gibberellic acid $\left(\mathrm{GA}_{3}, 5 \mathrm{mg} \mathrm{L}^{-1}\right)$; T5) calcium chloride $\left(\mathrm{CaCl}_{2}, 20 \mathrm{~g} \mathrm{~L}^{-1}\right)$ and T6) Sodium Thiosulphate (STS, $20 \mathrm{mM}$ ). The effect of preservative solutions were assessed daily, considering the longevity of flowers, variation in the absorption of preservative solution, $\mathrm{pH}$ of the solution and fresh mass variation. The experimental design was completely randomized with four replicates. There was a difference in carbohydrate metabolism during floral opening and senescence. In the orange bracts there was a lower TSS content, while in the inflorescences it was observed a reduction in the yellowish, greenish-green and greenish stages. The content of RS increased in the bracts, whereas in the inflorescence there was no difference. The NRS content was higher in the orange bracts, showing lower rates in the inflorescences in yellowish and yellowish greenish stages. The preservative solutions had an impact, on the floral stem longevity, varying according to the solutions used, i.e. $\mathrm{CaCl}_{2}$ and STS reduced the durability of gerbera flower in 9.25 and 11.5 days, respectively, compared to stems kept in distilled water. The glucose solution did not promote a significant difference compared to water. Therefore, we conclude that there is variation in the metabolism of non-structural carbohydrates during the floral development of G. jamesonii var. Dawn and the tested solutions were not effective in promoting postharvest conservation of gerbera.
\end{abstract}

Keywords: Gerbera jamesonii, sugars, floral stem, preservative solutions.

\section{RESUMO}

Metabolismo de carboidratos não estruturais e conservação pós-colheita de gérbera

A espécie Gerbera jamesonii Adlam tem grande importância econômica no setor ornamental, devido à exuberância das hastes florais. Contudo, os floricultores enfrentam alguns entraves como o manuseio pós-colheita e a dificuldade de conservação. Assim, este trabalho teve como objetivo caracterizar o metabolismo de carboidratos não estruturais das hastes florais de G. jamesonii var. Dawn e avaliar o efeito de soluções conservantes ao longo do armazenamento pós-colheita. Para este propósito, quantificou-se o teor de açúcar solúvel total (AST), açúcar redutor (AR) e açúcar não redutor (ANR) de brácteas e inflorescências de gérbera, classificadas em sete estádios (E1, E2, E3, E4, E5, E6 e E7). As soluções conservantes usadas foram: T1) Água destilada; T2) Ácido cítrico (100 mg L-1 $)$; T3) Glicose (20 $\left.\mathrm{g} \mathrm{L}^{-1}\right)$; T4) Ácido giberélico $\left(\mathrm{GA}_{3}, 5 \mathrm{mg} \mathrm{L}^{-1}\right)$; T5) Cloreto de cálcio $\left(\mathrm{CaCl}_{2}, 20 \mathrm{~g} \mathrm{~L}^{-1}\right)$ e T6) Tiossulfato de sódio (STS, 0,2 mM). Os efeitos das soluções conservantes foram avaliados diariamente, considerando a longevidade das flores, variação na absorção de solução conservante, $\mathrm{pH}$ da solução e variação de massa fresca. O delineamento utilizado foi inteiramente casualizado, com quatro repetições. Houve diferença no metabolismo de carboidrato durante a abertura floral e senescência. Nas brácteas alaranjadas houve menor teor de TSS, enquanto que nas inflorescências observou-se redução nos estádios de coloração amarelada, amarela esverdeada e esverdeada. O conteúdo de RS aumentou nas brácteas, já na inflorescência não houve diferença. O teor de NRS foi maior nas brácteas alaranjadas, já nas inflorescências os estádios de cor amarelada e amarela esverdeada foram menores. Quanto ao efeito das soluções conservantes, constatou-se que a longevidade das hastes florais variou conforme as soluções utilizadas, sendo que as soluções $\mathrm{CaCl}_{2}$ e STS reduziram a durabilidade de flor de gérbera em 9,25 e 11,5 dias, respectivamente, comparado as hastes mantidas em água destilada. Já a solução de glicose não promoveu diferença significativa comparada à água. Portanto, conclui-se que há variação no metabolismo de carboidratos não estruturais durante o desenvolvimento floral de G. jamesonii var. Dawn e as soluções testadas não foram efetivas em promover a conservação pós-colheita de gérbera.

Palavras-chave: Gerbera jamesonii, açúcares, hastes florais, soluções conservantes.

DOI: http://dx.doi.org/10.14295/oh.v23i3.1079

${ }^{(1)}$ Received in 04/07/2017 and accepted in 23/08/2017.

${ }^{(2)}$ Universidade Federal do Oeste da Bahia, Centro das Ciências Biológicas e da Saúde, Barreiras-BA, Brazil.

${ }^{(3)}$ Universidade do Estado do Mato Grosso, Departamento de Agronomia, Cáceres-MT, Brazil.

Licensed by CC BY 4.0 


\section{INTRODUCTION}

The Brazilian floriculture has acquired remarkable values in the last years, characterizing itself as one of the most promising agribusiness segments. In this scenario, Gerbera jamesonii Adlam, known as gerbera, plays an important role (GUERRERO et al., 2012), being the fourth cut flower most commercialized in the domestic market and second most exported by Brazil (JUNQUEIRA and PEETZ, 2008), with uses in event decoration and floral arrangements (LUDWIG et al., 2010).

However, one of the barriers faced by floriculture is the proper postharvest handling protocols for the different species and cultivars (ASGHARI et al., 2014; SARDOEI and SHAHDADNEGHAD, 2014), as the consumer market demand for flowers in a very good state of conservation and with high durability.

The postharvest durability of the flowers is a result of physiological changes and depends on the amount of reserves, especially carbohydrates, as well as on other factors that may negatively influence, including occurrence of bacteria and fungi, physical injury to tissues and excessive loss of water. It is noted that the main cause of senescence of cut flowers is the loss of energy and water, which are necessary for the maintenance of vital processes (BRACKMANN et al., 2004).

The process of senescence varies between species and requires the optimization of water relations, reduction of abscission or wilting, control of microorganisms growth (FINGER et al., 2004), besides the respiratory regulation, which involves the exhaustion of reserves, especially carbohydrates. Thus, the carbohydrates present in the flower tissues interfere in the longevity of the same. In order to supply the floral stem metabolism, carbohydrates are translocated from the leaves to the tissues of the petals, mainly sucrose (non-reducing sugar), which will be reduced by hydrolysis by the action of invertases and sucrose synthase, releasing glucose and fructose, that promote an increase in the concentration of solutes in the flowers and, consequently, reduction of the water potential, favoring the absorption of the solution (TAIZ and ZEIGER, 2013).

Due to the high perishability of flowers, it is necessary to develop and use techniques that promote their durability, maintaining the characteristics of the product and reducing postharvest losses (FISCHER et al., 2015). The alternatives are the use of preservative solutions, i.e. normally a mix of sugars, and germicides, application of ethylene inhibitors, growth regulators and some mineral compounds, which can maintain the quality and prolong the vase life of the stems by the maintenance of sugars levels, tissue hydration and senescence regulation (ALMEIDA et al., 2008). Thus, most preservative solutions present carbohydrates, mainly sucrose, that promote the replacement of respiratory substrates (LIMA et al., 2014), and citric acid, which reduces the $\mathrm{pH}$ of the water and, consequently, decreasing the proliferation of bacteria, which block the xylem vessels in the cut region, damaging the water balance (NOWAK and RUDNICKI, 1990).

The effects of preservative solutions containing carbohydrates were observed in several studies, being that optimum concentration of sugar used in postharvest varies significantly depending not only the species but also the cultivar to be treated.

Therefore, this study aimed to characterize the nonstructural carbohydrate content in different floral stages of G. jamesonii and evaluate the effect of preservative solutions during the postharvest storage of this species.

\section{MATERIAL AND METHODS}

The floral stems of G. jamesonii var. Dawn, in different stages of development, were produced in from Holambra$\mathrm{SP}$, and transported to Bahia. The selection criterion is related to the high commercialization of this variety in the state of Bahia. This variety is highly commercialized in the state of Bahia. The specimens were acquired packaged and kept in a cold chamber at $5{ }^{\circ} \mathrm{C}$ for 18 hours for acclimatization. At laboratory, the gerbera stems were re cut and standardized for the length of $15 \mathrm{~cm}$, of mechanical damages and attack of pathogens.

In the experiment of carbohydrates characterization of G. jamesonii, the samples were classified into seven stages: E1 - absence of bracts and yellowish inflorescence; E2 - greenish bracts and greenish yellow inflorescence; E3 - yellowish bracts and greenish yellow inflorescence; E4 yellowish bracts at base and orange at apex and greenish yellow inflorescence; E5 - spaced orange yellow bracts and greenish yellow inflorescence; E6 - orange bracts, closer together and greenish inflorescence (commercial point); E7 - discolored bracts with dark spots and greenish inflorescences.

The extraction was accomplished by manually grinding the samples and mixing with ethanol $80 \%(\mathrm{v} / \mathrm{v})$, followed by filtering. It was used the phenol-sulfuric acid to quantify the total soluble sugars (TSS) (DUBOIS et al., 1956). The reducing sugars (RS) were determined by the SomogyNelson method (NELSON, 1944). The non-reducing sugars (NRS) were estimated by subtracting the reducing sugars content from the total soluble sugars content.

To evaluate the effect of the preservative solutions on the longevity of G. jamesonii, the stems were kept in glass vessels with $125 \mathrm{~mL}$ of each of the following solutions: T1 - Distilled water, T2 - Citric acid (100 mg L'), T3 - Glucose $\left(20 \mathrm{~L}^{1}\right), \mathrm{T} 4$ - Gibberellic acid $\left.\left(\mathrm{GA}_{3}, 5 \mathrm{mg} \mathrm{L}\right)^{1}\right), \mathrm{T} 5$ - Calcium chloride $\left(\mathrm{CaCl}_{2}, 20 \mathrm{~g} \mathrm{~L}^{-1}\right)$, T6 - Silver thiosulfate (STS, $0.2 \mathrm{mM}$ ). The volume was replaced with water/solution or renovated every two days.

The stems were kept under controlled environment $\left(25^{\circ} \mathrm{C}\right)$, and constant photoperiod. The evaluations were carried out daily, considering:

- Longevity of flowers: number of days between cut and the loss of floral quality; 
- Preservative solution absorption: measured by volume determination;

- $\mathrm{pH}$ of the solution: determined using the digital pHmeter;

- Fresh mass variation: determined by daily weighing.

The experiments were conducted in a completely randomized design, with 4 replicates, with 2 stems as experimental unit. The data were interpreted using analysis of variance, and the means were compared by the Scott-Knott test at the 5\% probability level.

\section{RESULTS AND DISCUSSION}

During floral development of G. jamesonii, significant differences in carbohydrate levels were observed at different stages (Tables 1 and 2). In the total soluble sugar content of the bracts there was a reduction of approximately $52 \%$ in stages 5 and 6, compared to the others (Table 1), indicating consumption, probably due to the respiratory process, since in these stages there is energy demand for the synthesis of pigments and floral opening, which are necessary changes, since they are associated with the orange coloration.

Table 1. Carbohydrate metabolism in flower bracts structures of Gerbera jamesonii Adlam var. Dawn in different stages of development. TSS (Total Soluble Sugar), RS (Reducing Sugar) and NRS (Non-Reducing Sugar).

\begin{tabular}{|c|c|c|c|}
\hline Stadiums - Bracts & TSS (\%) & RS (\%) & NRS (\%) \\
\hline 1 & ---- & --- \\
\hline 2 & $8.86 \mathrm{a} \pm 0.05$ & $0.35 \mathrm{~b} \pm 0.08$ & $8.51 \mathrm{a} \pm 0.08$ \\
\hline 3 & $5.36 \mathrm{a} \pm 0.69$ & $0.51 \mathrm{~b} \pm 0.05$ & $4.84 \mathrm{~b} \pm 0.71$ \\
\hline 4 & $6.51 \mathrm{a} \pm 0.72$ & $0.39 \mathrm{~b} \pm 0.07$ & $6.11 \mathrm{~b} \pm 0.75$ \\
\hline 5 & $2.31 \mathrm{~b} \pm 0.07$ & $0.60 \mathrm{~b} \pm 0.07$ & $1.71 \mathrm{c} \pm 0.14$ \\
\hline 6 & $4.22 \mathrm{~b} \pm 0.26$ & $0.98 \mathrm{a} \pm 0.09$ & $3.23 \mathrm{c} \pm 0.32$ \\
\hline 7 & $6.48 \mathrm{a} \pm 1.08$ & $1.37 \mathrm{a} \pm 0.18$ & $5.10 \mathrm{~b} \pm 0.92$ \\
\hline
\end{tabular}

Means followed by the same letter in the column do not differ by Scott-Knott test at 5\% probability level. Mean \pm standard error. E1-absence of bracts; E2- greenish bracts; E3-yellowish bracts; E4- yellowish bracts at the base and orange at the apex; E5- yellow orange bracts; E6-orange bracts, Closer together (commercial point); E7-discolored bracts and with dark spots.

The high amount in the senescence stage of the flower (E7) demonstrates the possibility of carbohydrate concentration, due to the loss of water, once the wilting began. In relation to the total soluble sugar content of the inflorescences, there was a decrease in the initial (E1 and E2) and final (E6 and E7) stages, indicating that there was low production and high consumption, respectively (Table 2).

Table 2. Carbohydrate metabolism in the floral structures of inflorescences of Gerbera jamesonii Adlam var. Dawn in different stages of development. TSS (Total Soluble Sugar), RS (Reducing Sugar) and NRS (Non-Reducing Sugar)

\begin{tabular}{|c|c|c|c|}
\hline Stadiums - Inflorescences & TSS (\%) & RS (\%) & NRS (\%) \\
\hline 1 & $2.28 \mathrm{c} \pm 0.06$ & $0.92 \mathrm{a} \pm 0.14$ & $1.35 \mathrm{c} \pm 0.17$ \\
\hline 2 & $1.96 \mathrm{c} \pm 0.19$ & $0.65 \mathrm{a} \pm 0.08$ & $1.31 \mathrm{c} \pm 0.25$ \\
\hline 3 & $9.16 \mathrm{a} \pm 0.01$ & $0.59 \mathrm{a} \pm 0.07$ & $8.56 \mathrm{a} \pm 0.07$ \\
\hline 4 & $2.93 \mathrm{c} \pm 0.82$ & $0.61 \mathrm{a} \pm 0.03$ & $2.26 \mathrm{c} \pm 0.81$ \\
\hline 5 & $8.54 \mathrm{a} \pm 0.21$ & $0.69 \mathrm{a} \pm 0.06$ & $7.85 \mathrm{a} \pm 0.14$ \\
\hline 6 & $5.27 \mathrm{~b} \pm 0.35$ & $0.68 \mathrm{a} \pm 0.09$ & $4.58 \mathrm{~b} \pm 0.43$ \\
\hline 7 & $4.69 \mathrm{~b} \pm 0.12$ & $0.87 \mathrm{a} \pm 0.09$ & $3.81 \mathrm{~b} \pm 0.03$ \\
\hline
\end{tabular}

Means followed by the same letter in the column do not differ by Scott-Knott test at $5 \%$ probability level. Mean \pm standard error. E1 - yellowish inflorescence; E2 - greenish yellow fluorescence; E3 - greenish yellow inflorescence; E4 - greenish yellow inflorescence; E5 - yellowish base and orange bracts at apex and greenish yellow inflorescence; E6 - greenish inflorescence (commercial point); E7 - discolored bracts with dark spots and greenish inflorescences.

Muniz et al. (2016) have verified that ligules of inflorescences of gerberas 'Intenza' showed values of total soluble sugar of $0.47 \%$, being this $9 \mathrm{x}$ smaller that did not find work for inflorescences at the commercial point. The data confirm the importance of the carbohydrate reserve for floral longevity, due to the proportionality between these parameters.
Regarding the reducing sugar content of the bracts, it noted an increase during floral development, being that the stages 6 and 7, represented by fully open flowers and senescent flowers, respectively, presented an increase of 2.5 times in relation to the other stages (Table 1). This increase may be due to the degradation of sucrose, resulting 
in glucose and fructose, which accumulate in the flowers, increasing the solutes concentration and, consequently, favoring the maintenance of the petals turgescence (ELHINDI, 2012). In addition, the reducing sugars will be used in the respiration to produce energy used for floral opening or in the formation of metabolic intermediates (TAIZ and ZEIGER, 2013), confirming previous data. In the inflorescences, there was no significant difference between the stages (Table 2).

The behavior of the non-reducing sugar occurred similarly to bracts in stages 5 and 6 , because was found reduction of approximately $70 \%$ in comparison to the other stages (Table 1), agreeing with the hypothesis that the increase in the content of total soluble sugar refers to the degradation of sucrose, releasing glucose and fructose. In relation to the non-reducing sugar content of the inflorescences, this presented lower values in stages 1 ,
2 and 4 , being a decrease of about $80 \%$ compared to the others (Table 2). The results were similar to those found in E. ibaguense flowers, because the non-reducing sugar content increased during the postharvest life with a mean of 44.47\% (MAPELI et al., 2009). Thus, the characterization of carbohydrates can be useful tools in ornamental horticultural studies.

Regarding the effect of preservative solutions on postharvest quality of gerbera, different effects were observed, depending on the considered parameter. In relation to the longevity of $G$. jamesonii, the floral stems submitted to glucose did not differ from the control (Table 3 ). However, the use of citric acid and $\mathrm{GA}_{3}$ significantly reduced floral durability, in 1.5 and 4.25 days, respectively, compared to the control. This decrease was even more intense in the stems maintained in $\mathrm{CaCl}_{2}$ and STS, since the decrease was 9.25 and 11.5 days, respectively (Table 3).

Table 3. Effect of preservative solutions on total longevity stems of Gerbera jamesonii Adlam var. Dawn.

\begin{tabular}{|c|c|}
\hline Preservative solution & Longevity \\
\hline Control & $12.5 \mathrm{a}$ \\
\hline Citric Acid & $10.0 \mathrm{~b}$ \\
\hline Glucose & $13.5 \mathrm{a}$ \\
\hline $\mathrm{GA}_{3}$ & $8.25 \mathrm{c}$ \\
\hline $\mathrm{CaCl}_{2}$ & $3.25 \mathrm{~d}$ \\
\hline $\mathrm{STS}$ & $1.00 \mathrm{e}$ \\
\hline
\end{tabular}

Means followed by the same letter do not differ by Scott-Knott test at 5\% probability level.

The harmful effect observed by STS exposure can be explained by the oxidation of the stem base and discoloration of the petals, probably due to the loss of water and the high respiratory rates (DAI and PAULL, 1991).

In addition, in the STS treatment may have occurred xylem obstruction, due to microbial or physiological causes, compromising the absorption of the solution, since it was less absorbed than the other treatments (Table 4), which caused a negative water balance resulting from a water absorption rate lower than the transpiration rate, inducing the loss of early turgidity of the petals, limiting the life of the flowers (VAN MEETEREN et al., 2006). 
Table 4. Effect of preservative solutions (PS) on the variation of absorption (\%) on stems of Gerbera jamesonii Adlam var. Dawn.

\begin{tabular}{|c|c|c|c|c|c|c|c|c|c|c|c|}
\hline PS & D1 & D2 & D3 & D4 & D5 & D6 & D7 & D8 & D9 & D10 & D11 \\
\hline 1 & $1.4 \mathrm{c} \pm 0.3$ & $3.4 \mathrm{a} \pm 0.2$ & $8.2 \mathrm{~b} \pm 0.5$ & $9.0 \mathrm{~b} \pm 0.7$ & $9.0 \mathrm{~b} \pm 0.7$ & $18.4 \mathrm{~b} \pm 1.6$ & $18.0 \mathrm{~b} \pm 1.7$ & $22.4 \mathrm{~b} \pm 1.8$ & $24.4 \mathrm{~b} \pm 2.1$ & $28.0 \mathrm{~b} \pm 1.4$ & $27.6 \mathrm{a} \pm 0.7$ \\
\hline 2 & $2.2 \mathrm{~b} \pm 0.1$ & $2.8 \mathrm{a} \pm 0.0$ & $7.2 \mathrm{~b} \pm 0.6$ & $10.8 \mathrm{~b} \pm 0.7$ & $10.8 b \pm 0.8$ & $19.4 \mathrm{~b} \pm 1.1$ & $22.4 b \pm 1.2$ & $22.7 b \pm 1.4$ & $28.4 b \pm 1.6$ & $35.2 \mathrm{~b} \pm 1.6$ & $33.6 \mathrm{a} \pm 1.6$ \\
\hline 3 & $2.1 \mathrm{~b} \pm 0.1$ & $3.1 \mathrm{a} \pm 0.1$ & $9.0 \mathrm{~b} \pm 0.5$ & $13.2 \mathrm{~b} \pm 1.2$ & $13.2 \mathrm{~b} \pm 1.1$ & $15.6 \mathrm{~b} \pm 1.3$ & $19.8 b \pm 1.5$ & $22.4 b \pm 1.6$ & $26.2 b \pm 1.7$ & $29.8 \mathrm{~b} \pm 2.0$ & $31.2 \mathrm{a} \pm 0.6$ \\
\hline 4 & $3.1 \mathrm{a} \pm 0.1$ & $5.3 \mathrm{a} \pm 0.2$ & $12.2 \mathrm{a} \pm 0.7$ & $18.4 \mathrm{a} \pm 1.4$ & $18.4 \mathrm{a} \pm 0.7$ & $25.4 \mathrm{a} \pm 1.5$ & $30.8 \mathrm{a} \pm 2.2$ & $32.2 \mathrm{a} \pm 1.9$ & $44.8 \mathrm{a} \pm 3.8$ & $48.0 \mathrm{a} \pm 83.8$ & --- \\
\hline 5 & $1.4 \mathrm{c} \pm 0.1$ & $2.5 \mathrm{a} \pm 0.0$ & $4.8 \mathrm{c} \pm 0.2$ & $9.2 b \pm 0.2$ & $9.2 \mathrm{~b} \pm 0.0$ & --- & --- & --- & --- & --- & --- \\
\hline 6 & $1.0 \mathrm{c} \pm 0.4$ & $5.2 \mathrm{a} \pm 1.5$ & --- & --- & --- & --- & --- & --- & --- & --- & --- \\
\hline
\end{tabular}

Means followed by the same letter in the column do not differ by Scott-Knott test at 5\% probability level. 1-control; 2-citric acid; 3-glucose; 4-GA; $5-\mathrm{CaCl}_{2} ; 6-\mathrm{STS}$.

STS is formed from the reaction between silver nitrate and sodium thiosulfate and the resulting product blocks the ethylene action by competing with its binding (KUMAR et al., 2009). For cut flowers, it has been preferred to use STS, due to the good mobility in the plant and to present smaller problems of phytotoxicity, besides presenting germicidal effects (FLORACK et al., 1996). However, in the present study it was demonstrated inefficiency, agreeing with results obtained by Dai and Paull (1991) when flower stems of Alstroemeria sp. were maintained in $4 \mathrm{mM}$ of STS, for 24 hours, as they observed that this did not improve vase life, but accelerated the yellowing of the leaves. It is known that the ethylene negatively affects postharvest of gerbera, leading to acceleration of senescence (NOWAK and RUDNICKI, 1990).

Carbohydrates are the main sources of energy for the maintenance of all the biochemical and physiological processes of the flowers after the separation of the mother plant (MOALEM-BENO et al., 1997), besides inhibiting the production and the action of ethylene, improve water balance and regulate stomatal closure, reducing transpiration (BIELESKI, 1993). However, the use of glucose in the present study reduced the vase life in two days compared to stems kept in deionized water (control). The absence of a positive glucose effect can be linked to the higher reducing sugar content in E6, showing that the species already has sufficient amount of reducing sugar to be used as an energy source, as previously noted (Table 1), supporting the relevance of characterizing carbohydrates, constituting a new tool in postharvest studies.

The fresh mass variation analysis evidenced that practically all treatments induced elevated loss of fresh mass, except the glucose treatment. Most intense effect in the floral stems kept in the deionized water (control) and in citric acid, at the end of the vase life weight reduced 47.5 and $38 \%$, respectively. However, in the stems submitted to glucose, $\mathrm{GA}_{3}, \mathrm{CaCl}_{2}$ and STS treatments, the fresh mass reduction was less intense, not reaching $20 \%$. Although they differ as to longevity, being higher in glucose with a mean duration of 13 days and the lowest in $\mathrm{CaCl}_{2}$ and STS lasting 4 days and 1 day, respectively (Figure 1). 

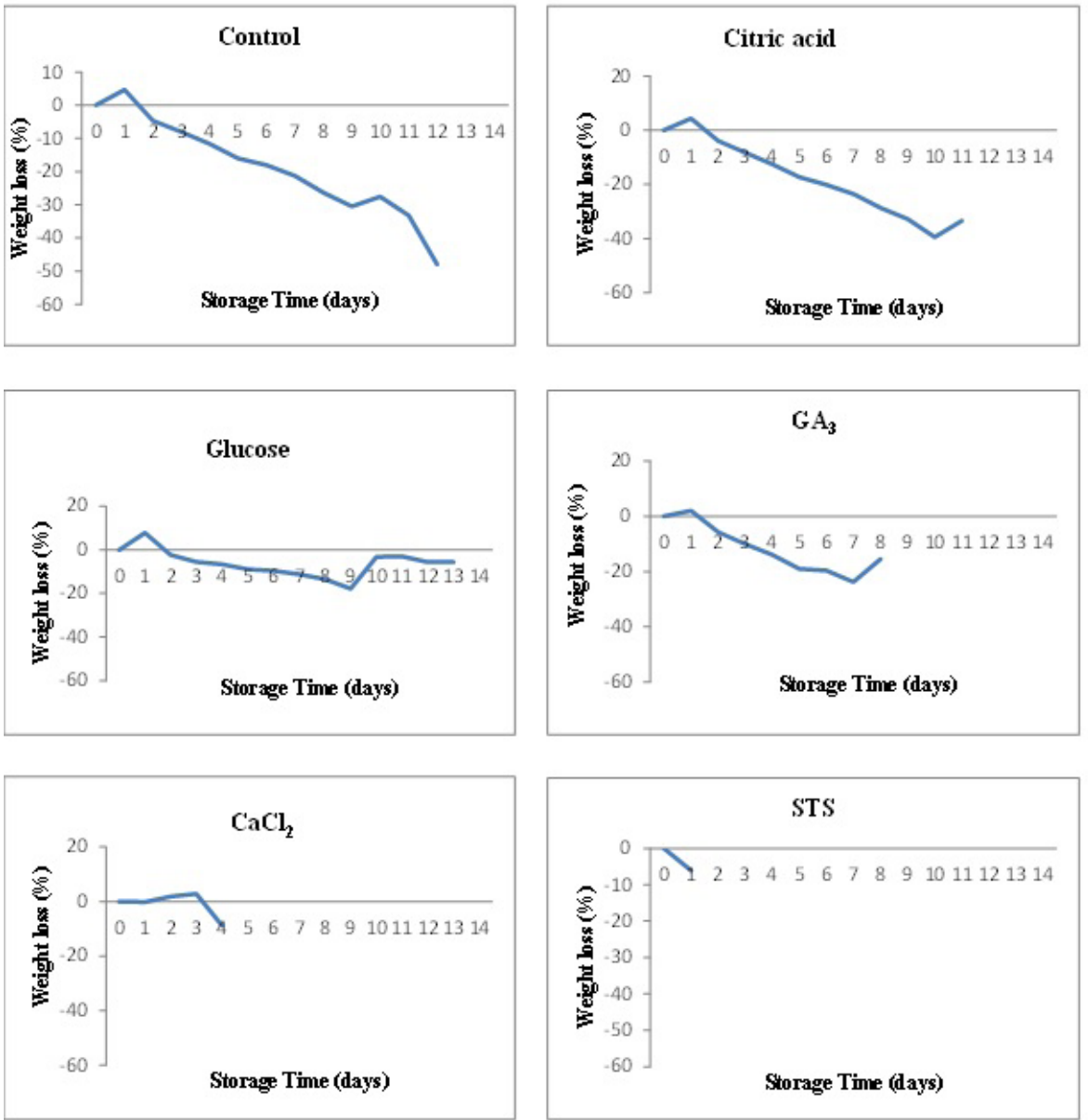

Figure 1. Effect of different preservative solutions on fresh mass variation (\%) in relation to initial mass of stems of Gerbera jamesonii Adlam var. Dawn.

The results obtained for fresh mass corroborate with the literature, since the plant tends to gain weight at the beginning of storage, but with the advance of senescence they lose water and wilt rapidly (TAIZ and ZEIGER, 2013), as the continuity of the physiological processes, i.e. respiration and transpiration.

Regarding the variation in the absorption of preservative solution, it was observed that the reduction was proportional to the days. After the second day of storage, the floral stems maintained in $\mathrm{GA}_{3}$ presented higher absorption when compared to the other treatments (Table 4), ince solutions with low doses of gibberellic acid favor the absorption (LASCHI et al., 1999). Similar data were observed in postharvest studies of chrysanthemum 'Reagan', as the stems exposed to the solution containing gibberellic acid induced greater absorption, promoting an increase in flower durability in 2.2 days (LASCHI et al., 1999).

In relation to $\mathrm{pH}$, the solution containing STS was more alkaline, whereas higher acidity was observed in the solution containing glucose (Table 5). 
Table 5. Effect of preservative solutions (PS) on the variation of pH on stems of Gerbera jamesonii Adlam var. Dawn.

\begin{tabular}{|c|c|c|c|c|c|c|c|c|c|c|c|}
\hline PS & D1 & D2 & D3 & D4 & D5 & D6 & D7 & D8 & D9 & D10 & D11 \\
\hline 1 & $6.9 \mathrm{a} \pm 0.0$ & $6.7 b \pm 0.0$ & $5.9 \mathrm{a} \pm 0.0$ & $6.0 \mathrm{~b} \pm 0.1$ & $5.4 \mathrm{~b} \pm 0.2$ & $5.3 \mathrm{c} \pm 0.1$ & $5.6 \mathrm{c} \pm 0.1$ & $5.3 \mathrm{~b} \pm 0.2$ & $5.4 \mathrm{~b} \pm 0.2$ & $5.5 \mathrm{~b} \pm 0.2$ & $4.9 \mathrm{~b} \pm 0.1$ \\
\hline 2 & $4.82 \mathrm{c} \pm 0.1$ & $6.4 b \pm 0.2$ & $6.3 \mathrm{a} \pm 0.1$ & $6.5 \mathrm{a} \pm 0.0$ & $6.2 \mathrm{a} \pm 0.1$ & $6.5 \mathrm{a} \pm 0.0$ & $6.7 \mathrm{a} \pm 0.0$ & $6.7 \mathrm{a} \pm 0.0$ & $6.6 \mathrm{a} \pm 0.0$ & $6.6 \mathrm{a} \pm 0.0$ & $5.9 \mathrm{a} \pm 0.1$ \\
\hline 3 & $6.0 \mathrm{~b} \pm 0.1$ & $4.7 \mathrm{c} \pm 0.0$ & $3.9 \mathrm{~b} \pm 0.0$ & $3.5 \mathrm{c} \pm 0.0$ & $3.1 \mathrm{c} \pm 0.0$ & $3.0 \mathrm{~d} \pm 0.0$ & $3.1 \mathrm{~d} \pm 0.0$ & $3.0 \mathrm{c} \pm 0.0$ & $3.0 \mathrm{c} \pm 0.0$ & $3.0 \mathrm{c} \pm 0.0$ & $2.9 \mathrm{c} \pm 0.0$ \\
\hline 4 & $7.1 \mathrm{a} \pm 0.0$ & $6.7 \mathrm{~b} \pm 0.0$ & $6.0 \mathrm{a} \pm 0.0$ & $5.7 \mathrm{~b} \pm 0.0$ & $5.3 \mathrm{~b} \pm 0.0$ & $5.8 \mathrm{~b} \pm 0.0$ & $6.2 \mathrm{~b} \pm 0.0$ & $6.5 \mathrm{a} \pm 0.0$ & $5.9 \mathrm{~b} \pm 0.0$ & $5.9 \mathrm{~b} \pm 0.0$ & --- \\
\hline 5 & $5.9 \mathrm{~b} \pm 0.1$ & $6.2 \mathrm{~b} \pm 0.0$ & $6.1 \mathrm{a} \pm 0.0$ & $6.0 \mathrm{~b} \pm 0.2$ & $6.2 \mathrm{a} \pm 0.0$ & -- & --- & --- & --- & --- & -- \\
\hline 6 & $7.3 \mathrm{a} \pm 0.0$ & $7.5 \mathrm{a} \pm 0.1$ & --- & -- & -- & -- & -- & --- & -- & -- & -- \\
\hline
\end{tabular}

Means followed by the same letter in the column do not differ by Scott-Knott test at 5\% probability level. 1-control; 2-citric acid; 3-glucose; 4-GA; $5-\mathrm{CaCl}_{2} ; 6-\mathrm{STS}$.

According to Carlson et al. (2015), many significant effects observed for conservative solutions are due to low $\mathrm{pH}$, which controls bacterial contamination, favoring the conservation of flowers. These data corroborate with that verified for gerbera, since the stems maintained in glucose presented greater durability, probably due to the low $\mathrm{pH}$ of the solution (Tables 3 and 5).

The $\mathrm{pH}$ influences the capacity of water absorption by the cut flowers, since water is more rapidly absorbed at acidic than alkaline pHs (FINGER and BARBOSA, 2005), justifying also the greater absorption of gibberellic acid during the experiment.

\section{CONCLUSIONS}

It was observed that there was variation in the carbohydrate content during the floral development of G. jamesonii. In addition, it was found that none of the tested solutions could be recommended for post-harvest preservation of gerbera, since no treatment was efficient.

\section{AUTHORS CONTRIBUTIONS}

A.M.O.S.A. and J.F.O.S.P. designed and performed experiments, analyzed the data, and drafted the article; G.F.S. and N.C.M. revised and complemented the writing; A.M.M. conceived the project, designed the work, analyzed the data, and wrote the article with contributions of all the authors.

\section{REFERENCES}

ALMEIDA, E.F.; PAIVA, P.D. de O.; LIMA, L.C. de O.; RESENDE, M.L.; FONSECA, J.; TAVARES, T.S. Pós-colheita de copo-de-leite: Efeito de diferentes conservantes comerciais e armazenamento a frio. Ciência Agrotecnologia, v.32, p.1189-1194, 2008. DOI: <http:// dx.doi.org/10.1590/S1413-70542008000400023>
ASGHARI, S.; SALARI, A.; GHAREHDAGHI, S. Effect of pulsing solution and packaging type under exogenous ethhylene on physiological characteristics and post harvesting quality of cut roses (Rosa hybrida). AmericanEurasian Journal of Agricultural \& Environmental Sciences, v.14, p.329-335, 2014. DOI: <http://dx.doi. org/10.5829/idosi.aejaes.2014.14.04.12323>

BIELESKI, R.L. Fructan hydrolysis drives petal expansion in the ephemeral daylily flower.

Plant Physiology, v.103, p.213-219, 1993. DOI: <https:// doi.org/10.1104/pp.103.1.213>

BRACKMANN, A.; SESTARI, I.; STEFFENS, C.A.; GIEHL, R.F.H. Qualidade da maçã cultivar Gala tratada com 1-metilciclopropeno. Ciência Rural, v.34, p.14151420, 2004. DOI: <http://dx.doi.org/10.1590/S0103$84782004000500014>$

CARLSON, A.S.; DOLE, J.M.; MATTHYSSE, A.G.; HOFFMANN, W.A.; KORNEGAY, J.L. Bacteria species and solution $\mathrm{pH}$ effect postharvest quality of cut Zinnia elegans. Scientia Horticulturae, v.194, p.71-78, 2015. DOI: <http://dx.doi.org/10.1016/j.scienta.2015.07.044>

DAI, J. W.; PAULL, R.E. Effect of water status on Dendrobium flower spray postharvest life. Journal of the American Society for Horticultural Science, v.116, p.491-496, 1991.

DUBOIS, M.; GILLES, K.A.; HAMILTON, J.K.; REBERS, P.A.; SMITH, F. Colorimetric method form determination of sugars and related substances. Nature, v.28, p.350-356, 1956. DOI: $<10.1021 / \mathrm{ac} 60111 \mathrm{a} 017>$ 
ELHINDI, K.M. Effects of postharvest pretreatments and preservative solutions on vase life longevity and flower quality of sweet pea (Lathyrus odoratus L.). Photosynthetica, v.50, p.371-379, 2012. DOI: <10.1007/ s11099-012-0053-3>

FINGER, F.L.; CARNEIRO, T.F.; BARBOSA, J.G. Senescência pós-colheita de inflorescências de esporinha (Consolida ajacis). Pesquisa Agropecuária Brasileira, v.39, p.533-537, 2004. DOI: < http://dx.doi.org/10.1590/ S0100-204X2004000600003>

FINGER, L.F; BARBOSA, J.G. Fisiologia e manejo póscolheita de flores tropicais. Estresses ambientais: danos e benefícios em plantas, v.1, p.287-295, 2005.

FISCHER, S.Z.; STUMPF, E.R.T.; CASTRO, C.M.; BARBIERI, R.L.; HEIDEN, G. Durabilidade de rosas, gérberas e crisântemo comercializados em Pelotas-RS. Ornamental Horticulture, v.21, p.113-118, 2015.

FLORACK, D.E.A.; STIEKEMA, W. J.; BOSCH, D. Toxicity of peptides to bacteria present in the vase water of cut roses. Postharvest Biology and Tecnology, v.8, p.285-291, 1996. DOI: <http://dx.doi.org/10.1016/09255214(96)00009-9>

GUERRERO, A.C.; FERNANDES, D.M.; LUDWIG, F. Acúmulo de nutrientes em gérbera de vaso em função de fontes e doses de potássio. Horticultura Brasileira, v.30, p.201-208, 2012. DOI: <http://dx.doi.org/10.1590/S0102$05362012000200004>$

JUNQUEIRA, A.H.; PEETZ, M.S. da. Mercado interno para os produtos da floricultura brasileira: características, tendências e importância socioeconômica recente. Revista Brasileira de Horticultura Ornamental, v.14, p.37-52, 2008.

KUMAR. V.; PARVATAN, G.; RAVISHANKAR, G.A. $\mathrm{AgNO}_{3}$ - a potential regulator of ethylene activity and plant growth modulator. Electronic Journal of Biotechnology, v.12, 2009. <DOI: 10.2225/vol12-issue2-fulltext-1>

LASCHI, D.; TAVARES, A. R.; RODRIGUES, J. D.; ONOI, E. O., MUÇOUCACHI, F. J.; GRANATO, S. Efeito de ácido giberélico, $\mathrm{GA}_{3}$ e $\mathrm{GA}_{4}+\mathrm{GA}_{7}$, em pós-colheita de crisântemo e solidago. Revista Brasileira de Horticultura e Ornamentais, v.5, p.143-149, 1999. DOI: <http://dx.doi. org/10.14295/rbho.v5i2.53>

LIMA, J.D.; MORAES, W.S; SILVA, C.M. Tecnologia pós-colheita de flores de corte. 2014. Disponível em: http://www.biologico.sp.gov.br/rifib/XIVRifib/lima.pdf. Acesso em: 29 de junho de 20140.
LUDWIG, F.; GUERRERO, A.C.; FERNANDES, D.M.; VILLAS BOAS, R.L. Análise de crescimento de gérbera de vaso conduzida em diferentes substratos. Horticultura Brasileira, v.28, p.70-74, 2010. DOI: <http://dx.doi. org/10.1590/S0102-05362010000100013>

MAPELI, A.M.; OLIVEIRA, L.S. de.; MEGGUER, C.A.; BARBOSA, J.G.; BARROS, R.S.; FINGER, F.L. Characterization of respiration, ethylene production and carbohydrate contents during flower opening in Epidendrum ibaguense. Journal of Horticultural Science \& Biotechnology, v.84, p.609-612, 2009. DOI: <http:// dx.doi.org/10.1080/14620316.2009.11512574>

MOALEM-BENO, D.; TAMARI, G.; LEITNER-DAGAN, Y.; WEISS, D. Sugar-dependent gibberellin-induced chalcone synthase gene expression in Petunia corollas. Plant Physiology, v.13, p. 419-424, 1997. DOI: <https:// doi.org/10.1104/pp.113.2.419>

MUNIZ, A.C.C.; GALATI, V.C.; MARQUES, K.M.; MATTIUZ, C.F.M.; MATTIUZ, B.H. Postharvest quality of red gerberas depending on the storage temperature. Ciência Rural, v.46, p. 1945-1951, 2016. DOI: <http:// dx.doi.org/10.1590/0103-8478cr20151627>

NELSON, N. A fotometric adaption of Somogy method for the determination of glucose. The Journal of Biological Chemistry, v.153, p.375-380, 1944.

NOWAK, J.; RUDNICKI, R.M. Postharvest handling and storage of cut flowers, florist greens and potted plant. Portland: Timber Press, 1990. 210p.

SARDOEI, A.S.; SHAHDADNEGHAD, M. Interaction effect of sucrose and salicylic acid on vase life of cut life Gerbera flowers. International Journal of Biological Science, v.1, p.31-36, 2014.

TAIZ, L.; ZEIGER, E. Fisiologia vegetal. 3ed. Porto Alegre: Artmed, 2013. 918p.

VAN MEETEREN, U.; GALARZA, L.A.; VAN DOORN, W.G. Inhibition of water uptake after dry storage of cut lowers: Role of aspired and wound- induced processes in Crysanthemum. Postharvest Biology and Technology, v.41, p.70-77, 2006. DOI: <10.1016/j. postharvbio.2006.03.005> 